\title{
REALIZATION AND CALIBRATION OF THE WIRELESS UV RADIATION MEASUREMENT SYSTEM
}

\author{
Z. Petrušić, U. Jovanović, I. Jovanović, D. Mančić* \\ University of Niš, Faculty of Electronic Engineering, A. Medvedeva 14, Serbia
}

\begin{abstract}
This paper reviews the realization of a simple wireless measurement system for measurement of UV radiation based on a photodiode as a sensor. The realized system was designed to be a constituent part of a photovoltaic tracking system and the associated weather station both currently developed at the Faculty of Electronic Engineering in Niš. The development of system hardware is presented as well as the calibration of the realized system and the test results obtained in the laboratory before and after calibration.
\end{abstract}

Keywords: UV radiation, photodiode, wireless measurement system, RF data transmission, calibration.

\section{INTRODUCTION}

The effectiveness of a photovoltaic (PV) cell depends on the choice of the light absorbing materials. Recently, a prototype of a new type of PV cell that generates electricity from visible, infrared (IR) and ultraviolet (UV) light has been demonstrated. Although it is still too early for big predictions this breakthrough could lead to the development of a new highly-efficient PV cells in the near future, without a need for multijunction cells. In PV tracking systems based on these cells, monitoring the intensity of UV radiation would be essential. High intensity of UV radiation can cause a degradation of crystalline-Si PV modules [1] making measurements of UV radiation important in the PV tracking systems based on these modules. Short wavelength UV light exhibits more quantum properties than its visible and infrared counterparts. UV light can be divided into three bands, according to its anecdotal effects as shown in Figure 1.

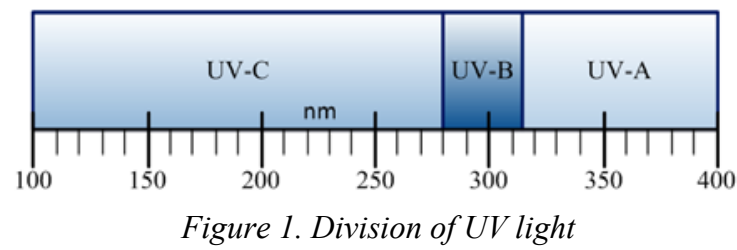

UV-A light $(315-400 \mathrm{~nm})$, often called a black light is used because of its ability to cause fluorescent materials to emit visible light that glows in the dark. It is relatively harmless and most tanning booths use UV-A lamps. UV-B light $(280-315 \mathrm{~nm})$ has enough energy to damage biological tissues and therefore is the most destructive form of UV light and is known to cause skin cancer. UV-C light (100 $-280 \mathrm{~nm}$ ) is almost completely absorbed in the air within a few hundred meters. UV-C lamps are often used to purify air and water, because of their ability to kill bacteria but they also cause the formation of ozone.

The level of UV radiation falling on a reception surface depends on a solar elevation angle (height of the Sun above the horizon), the altitude above the sea level, the annual variations in the distance between the Earth and the Sun, chemical structure of the atmosphere, clouds and reflecting power of the surface. Depending on the application of measurements, UV radiation is usually measured by highly sophisticated spectroradiometers or by simple filtered radiometers, whereby the most accurate measurements are obtained with high resolution UV spectroradiometers [2]. However, they can be quite expensive. For a large number of applications, measurements obtained with simpler, broadband UV radiometers and, by nowadays more popular, measurement devices based on semiconductor sensors, are precise enough.

Although there are many measurement systems currently available in the market, neither of them known to the authors of this paper is in fact a wireless system. Measurement system will be used outdoors in harsh environmental conditions; hence it would be impractical to use an expensive radiometer in such a manner. The development of a custom-

\footnotetext{
${ }^{*}$ Corresponding author: dragan.mancic@elfak.ni.ac.rs
} 
made system gives several benefits, the most important of which include its hardware and software flexibility, possibility to monitor and control the development costs, etc.

This paper presents the realization of the simple wireless measurement system for measurement intensity of UV radiation based on a photodiode as a sensor. It outlines the hardware structure of the realized system and its all functional parts. Several sources of UV radiation were tested during the calibration of the realized system. The system was designed in a way to be a constituent part of the PV tracking system and the weather station both currently developed at the Faculty of Electronic Engineering in Niš. The calibration of the realized system was performed, and the test results obtained before and after the calibration presented and compared against the commercial UV radiometer.

\section{UV LIGHT SENSORS}

Measurement of UV radiation in different bands requires the use of modern UV sensors [3] and adequate measurement systems [4]. Of course, the sensitivity to the concerned band is always a primary consideration when choosing an appropriate UV sensor. Depending on the sensing effect used by them, the UV radiation sensors can be divided into two main groups, photon and thermal sensors. The basic classification of UV sensors is shown in Figure 2.

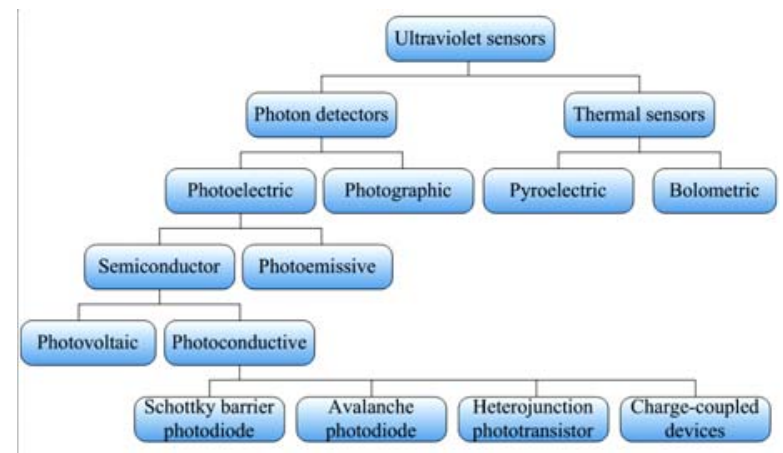

Figure 2. Classification of UV sensors

Since there are not many thermal UV sensors available in the market and that they do not give any benefits in comparison with photon sensors, there was no reason to consider them in the development of the measurement system. The most represented UV sensors available in the market are semiconductor sensors. Semiconductor UV sensors have a negative reaction on very high UV radiation thus inducing an aging effect in the majority of semiconductor materials. Because of that, the development of highly efficient semiconductor UV sensors was progressing slowly at one point of time. Semiconductor
UV sensors can be used either in a photoconductive or a photovoltaic mode. There are several types of photovoltaic sensors: Schottky barriers, PIN photodiodes, avalanche photodiodes, phototransistor with heterogeneous connection and charge-coupled devices (CCD). In general, semiconductor UV sensors represent a combination of photodiodes and adequate UV filters. Semiconductor sensors, such as UV photodiodes, convert the photons into an electrical current often called the photocurrent.

Since there are so many UV photodiodes available in the market at relatively low prices, one of them was used in the realized system as the sensor of UV radiation. It is a SG01L-5 photodiode made by Scitec Instruments with spectral characteristic shown in Figure 3 [5].

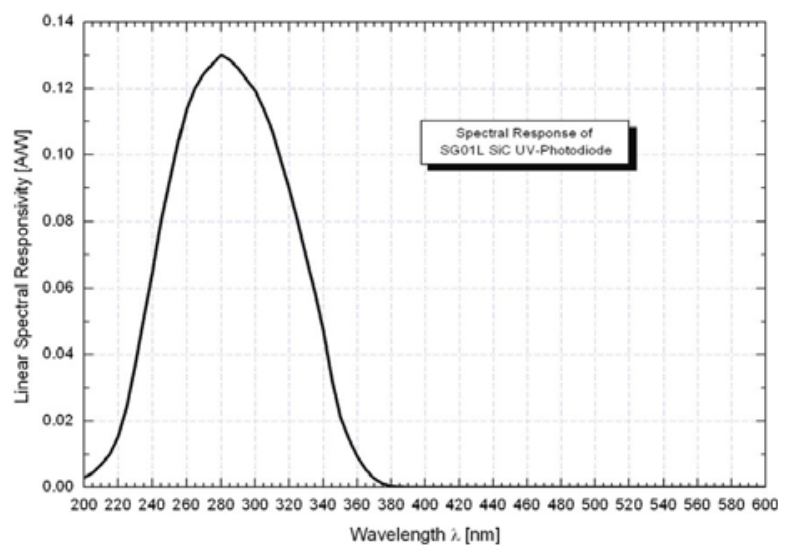

Figure 3. Spectral characteristic of the SG01L-5 UV photodiode [5]

The SG01L-5 photodiode is specially designed for extreme radiation hardness and is completely insensitive to visible light without the use of any filters, meaning that it only measures the UV part of a radiation spectrum even if visible light or infrared radiation is strongly present. This is a unique feature of photodiodes made by Scitec Instruments making this photodiode an ideal UV sensor for the realized system.

\section{STRUCTURE OF THE SYSTEM}

Because the SG01L-5 photodiode generates very small photocurrent (in range of $\mathrm{nA}$ ) it needs to be amplified and converted into adequate voltage with an appropriate gain which requires the use of a transimpedance amplifier as it is excellent for measuring within a fixed decade range along with the non-inverting amplifier [6,7]. The SG01L-5 photodiode is connected in the photovoltaic mode of operation in order to minimize the dark current. The detailed schematic diagram of the analog circuit used for conversion and amplification of the photo- 
current from the SG01L-5 photodiode is shown in Figure 4.

The photocurrent from the SG01L-5 photodiode is converted into voltage and amplified using the transimpedance amplifier composed of LPC660 operational amplifier and the resistor $R_{f}$. The capacitor $C_{f}$ is applied in parallel to the feedback resistor $R_{f}$ for stability reasons. The next stage is the active lowpass Sallen-key filter composed of LPC660 operational amplifier, $R_{1}$ and $R_{2}$ resistors and $C_{1}$ and $C_{2}$ capacitors. This filter is used to remove noise disturbance at the frequency of $50 \mathrm{~Hz}$. Voltage obtained in this way is then additionally amplified in the second amplifying stage which is basically the noninverting amplifier composed of LPC660 operational amplifier and $R_{3}$ and $R_{4}$ resistors. The final stage is the buffer (voltage follower) used to eliminate loading effects.

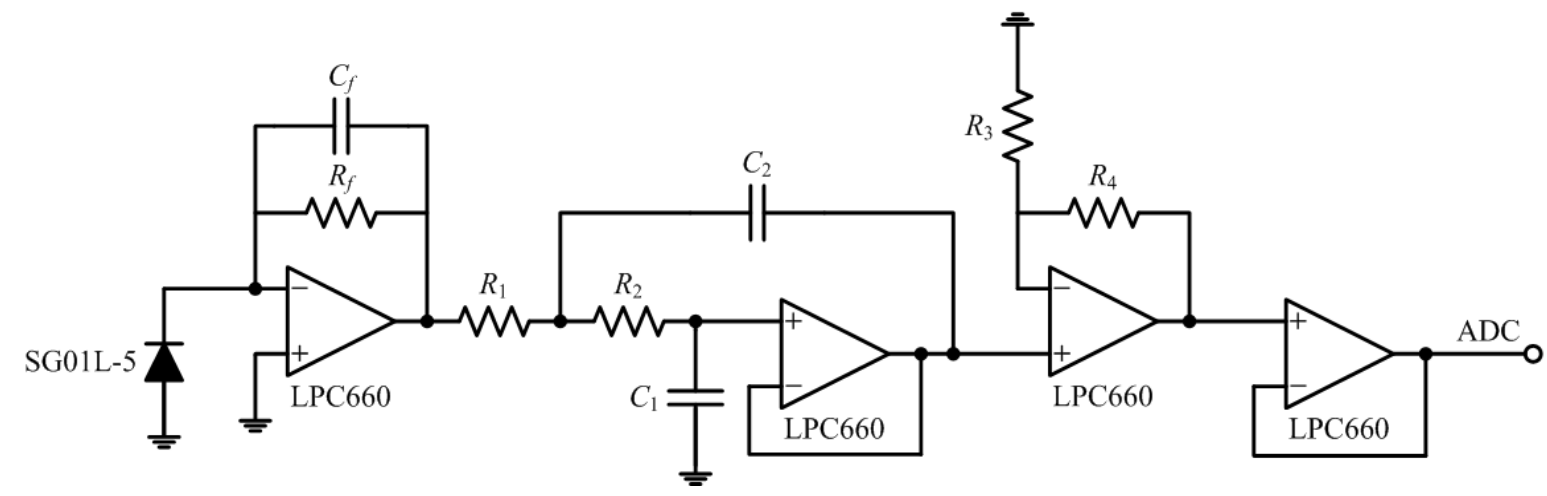

Figure 4. Detailed schematic of the analog circuit used for conversion and amplification of the photocurrent

The output voltage of the analog circuit, with maximal value of $4.5 \mathrm{~V}$ is then converted into digital form using the 10-bit A/D converter (ADC) of a microcontroller PIC18F4550. Because of the wireless data transmission the realized system is composed of two main units. The first unit named transmitting unit conducts continuous measurement of UV radiation and its sending measurement results to the second unit named a receiving unit which is connected to a central PC. Block diagram of the transmitting unit is shown in Figure 5a, and the photo of the realized unit is shown in Figure 5b.

The transmitting unit is based on the microcontroller PIC18F4550 because it is simple, reliable and inexpensive. It has a total of 13 10-bit analog inputs for $\mathrm{A} / \mathrm{D}$ conversion, enabling connection of multiple sensors. The transmitting unit transmits measurement results to the receiving unit wirelessly using a ST-TR1100 RF transceiver at the frequency of $433 \mathrm{MHz}$ with the transmission speed of 76.8 Kbits and FSK modulation. Measurement results can be displayed directly on the transmitting unit using the optional LCD display which represents a useful option while testing the realized system. By using the optional LCD display it is possible to dispense with the receiving unit making the realized system simpler.

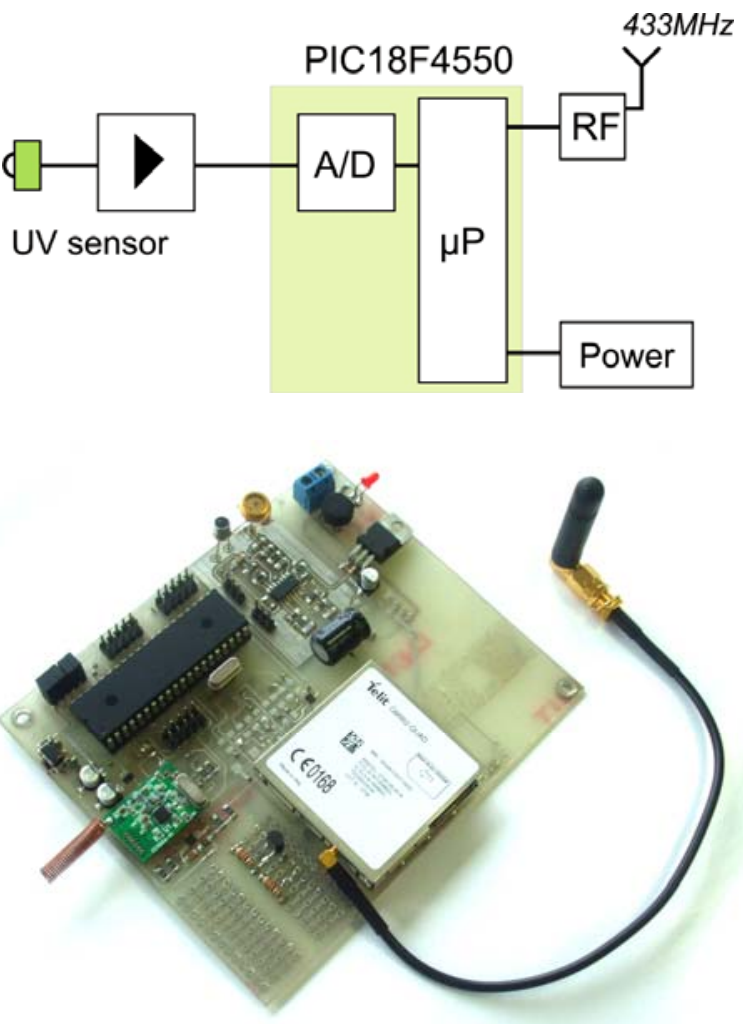

(b)

Figure 5. Transmitting unit: (a) block diagram; (b) photo of the unit 
The receiving unit is simpler than the transmitting unit and is composed of microcontroller PIC18F2550, ST-TR1100 RF transceiver and communicational interfaces. The receiving unit can be connected to a central PC via USB and serial port and it can also display measurement results on the optional LCD display if a PC is not available. Block diagram of the receiving unit is shown in Figure 6a, and the photo of the realized unit in Figure $6 b$.

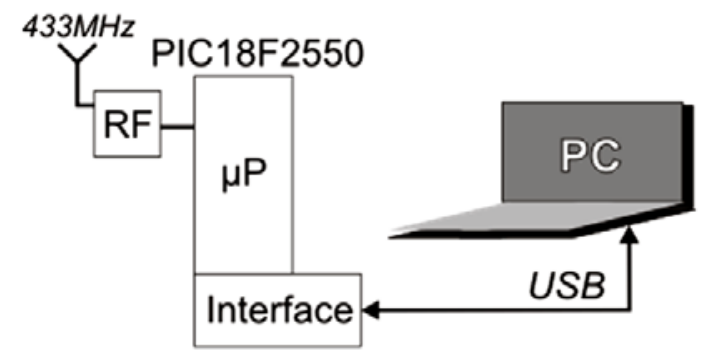

(a)

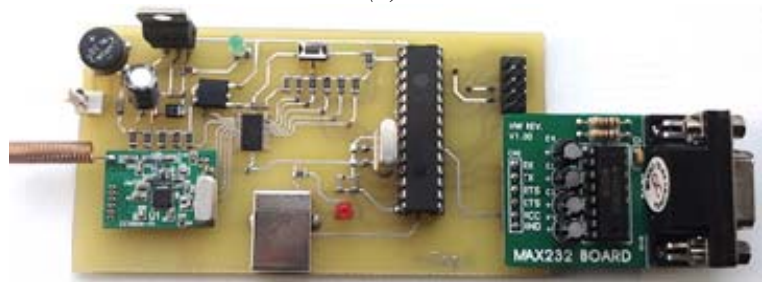

(b)

Figure 6. Receiving unit: (a) block diagram; (b) photo of the unit

The header of each message sent by the transmitting unit contains the unique address of the receiving unit. The receiving unit will reject all messages without its address in the header thus securing connection between units. The receiving unit will automatically reset if it doesn't receive any message with its address in the header within $20 \mathrm{~s}$ after receiving the last message. Upon each successfully received message with the valid header the receiving unit will send the confirmation message to the transmitting unit. The transmitting unit will continue measuring UV radiation and transmitting measurement results upon receiving this confirmation message. If the transmitting unit fails to receive this confirmation message within $20 \mathrm{~s}$ after sending the results of previous measurement it will automatically reset. These safety procedures conducted during data transmission significantly improve synchronization and reliability of the realized system while also reducing a number of errors in data transmission.

\section{CALIBRATION}

In order to calibrate the realized measurement system in the specific band it was necessary to use a calibrator or sources of UV radiation and a referent radiometer employed as a secondary measurement standard device [8]. Since calibrators are expensive a decision was made to use the sources of UV radiation and a secondary standard device along with the special calibrating platform. The calibration of the realized system was performed with maximum of $2.5 \mathrm{~mW} / \mathrm{cm}^{2}$. The radiometer YK-35UV made by Lutron was selected for the secondary standard device because it covers the range up to $20 \mathrm{~mW} / \mathrm{cm}^{2}$ with measurement accuracy of $4 \%$ and the resolution of $0.01 \mathrm{~mW} / \mathrm{cm}^{2}$ meeting the demands of the calibration procedure. The first used source of UV radiation was the UV lamp with the fluorescent black light blue (BLB) tube made by GE Lighting whose spectral characteristic is shown in Figure 7. The maximal radiation is emitted at $365 \mathrm{~nm}$.

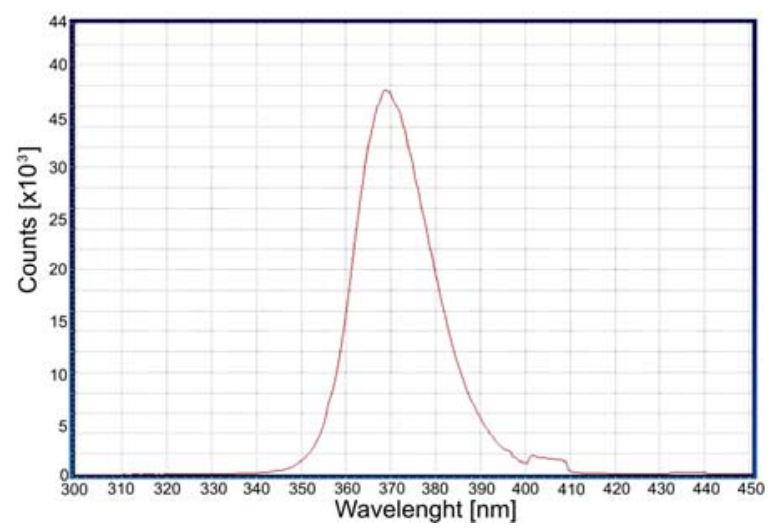

Figure 7. Spectral characteristic of the UV lamp with the fluorescent BLB tube

The second used source of UV radiation was the UV lamp HB411/B made by Philips with the HPA 400W lamp and spectral characteristic shown in Figure 8. As shown in Figure 8, the lamp has several high peaks outside the UV band and one inside the band.

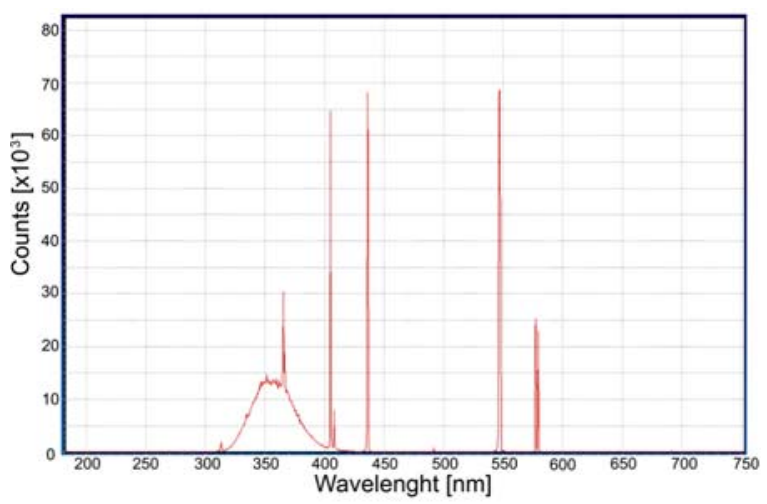

Figure 8. Spectral characteristic of the HB411/B lamp 
The third source of UV radiation used was the UV lamp TL29D16/09N made by Philips with the six $5 \mathrm{M} / 15 \mathrm{~W}$ tubes. The spectral characteristic of this lamp is shown in Figure 9 and it is almost identical to the previously mentioned UV lamp.

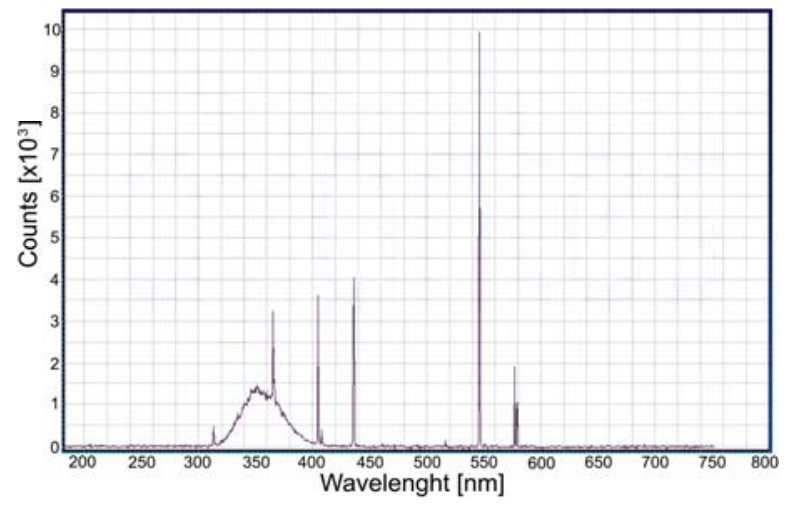

Figure 9. Spectral characteristic of the TL29D16/09N lamp

All displayed characteristics were obtained with the spectrometer AvaSpec-3648 made by Avantes with the measurement range between 200 and $720 \mathrm{~nm}$. Distribution of the light beam emitted from the UV lamp with fluorescent BLB tube is shown in Figure 10. As presented in Figure 10, the highest level of UV radiation is emitted directly in front of the lamp (the violet area between angles $-15^{\circ}$ and $15^{\circ}$ ) so for the realized system to be calibrated properly, it must be placed directly in front of the UV lamp along with the secondary standard device.

To make the calibration procedure as accurate as possible, the special custom-made movable line platform was employed and placed directly in front of the source of UV radiation in order to minimize the errors in UV radiation measurements [9].

The secondary standard device and the realized system are mounted on the movable mechanical structure horizontally in relation to the ground surface. Movable structure is placed directly in front of the source of UV radiation in order to precisely move them on to the positions away from the UV source with the precision of $0.05 \mathrm{~mm}$ per $1.5 \mathrm{~m}$. The movable line platform with mounted secondary standard and the realized system is shown in Figure 11.

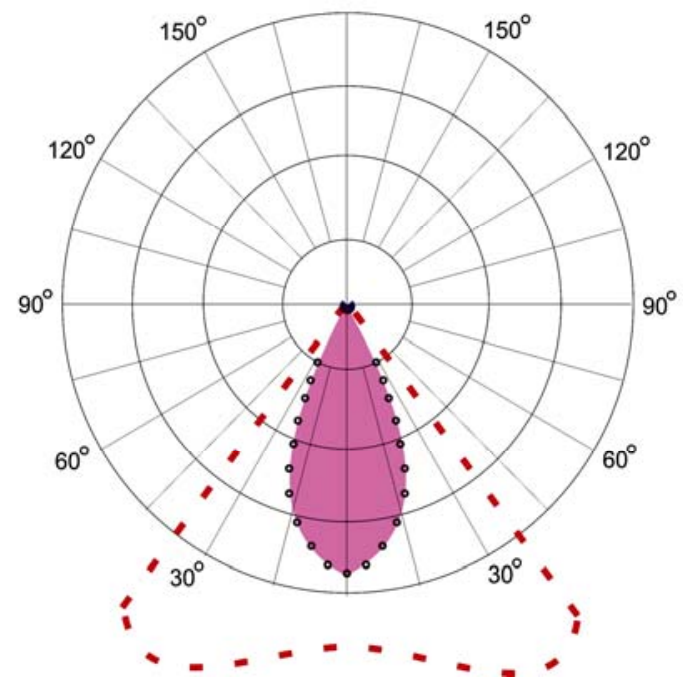

Figure 10. Distribution of UV light from the UV lamp with the fluorescent BLB tube

Movement of spiral spindles is achieved by a two-phase stepper motor MS 135/200 HT-2, with $1.8^{\circ}$ resolution. Movement of the movable structure on to the predefined positions and duration of the time it needs to stay put there are controlled with the PC application and an appropriate motor driver. A MD 24/28 motor driver made by Isel was used; it has the following characteristics: $4.2 \mathrm{~A}$ of output current, up to $300 \mathrm{kHz}$ of input frequency and automatic reduction of electric current. The functional block diagram of the calibration procedure conducted in the laboratory without the presence of any other source of light except UV radiation emitted by a UV lamp is shown in Figure 12.

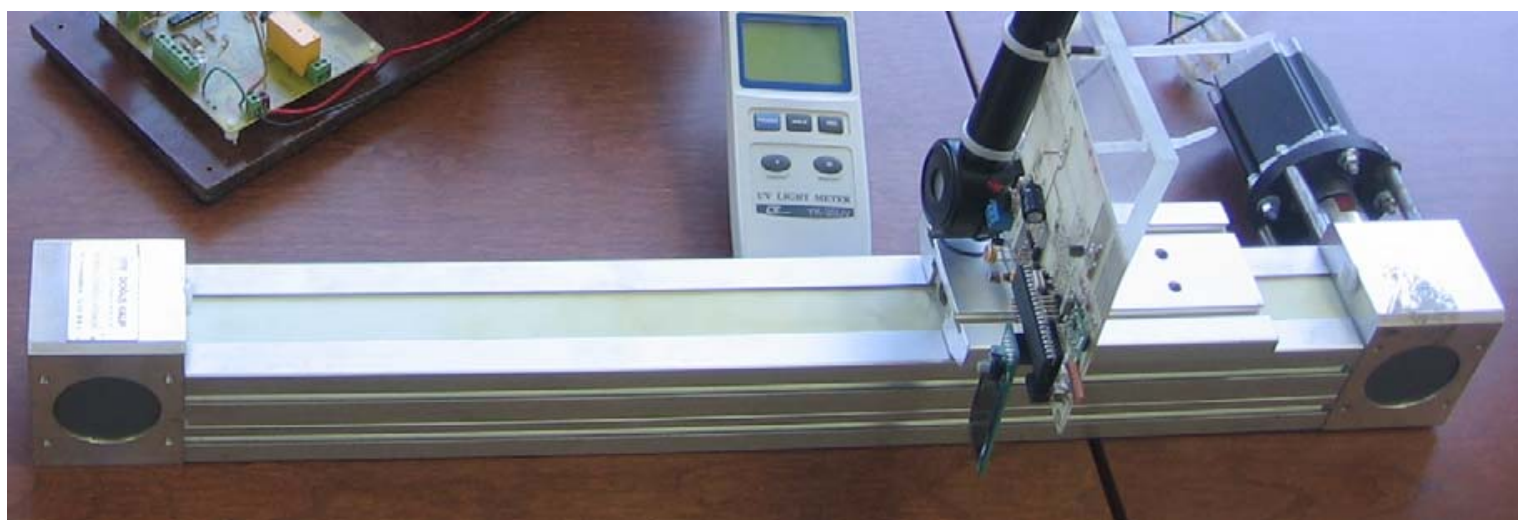

Figure 11. Movable line platform with mounted the secondary standard and the realized system 


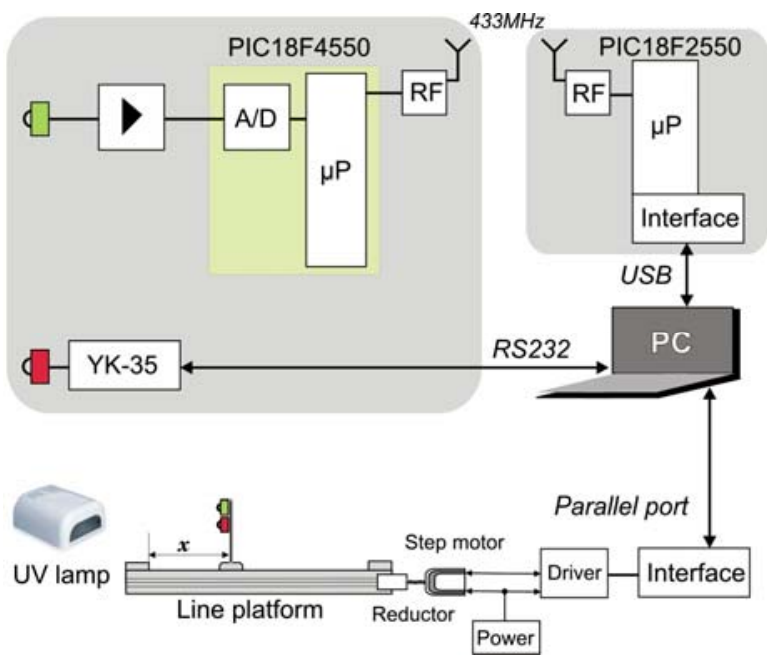

Figure 12. Functional block diagram of the calibration procedure

The comparison between measurements of the realized system and the secondary standard was done with all previously described sources of UV radiation. However, the UV lamp with the fluorescent BLB tube proved to be the best source of UV radiation. The calibration procedure requires a precise and steady movement of the secondary standard and the realized system on to the predefined points along the direction of UV radiation emitted from a UV lamp. Once it reaches a predefined point the movable structure stops moving and measurements are carried out after which the movable structure moves devices on to the next predefined point and so on until it reaches its final point. Once all measurements are carried out two corresponding measurement characteristics can be drawn (one for each device) and proper calibration coefficients can be calculated. Two measurement characteristics along with the normalized characteristic of the realized system obtained after the calibration are shown in Figure 13. Measurements were performed up to the distance of $1.52 \mathrm{~m}$ with the resolution of $4 \mathrm{~cm}$ using the UV lamp with the fluorescent BLB tube as the source of UV radiation.

As shown in Figure 13, the normalized characteristic (red circles) is almost a perfect match of the characteristic obtained from the secondary standard (green squares). The third characteristic (blue triangles) is the output voltage of the analog circuit shown in Figure 4 and measured by the ADC. The relative error is very small never exceeding $3 \%$ across the entire measurement range meaning that the calibration of the realized system was performed in a proper way.

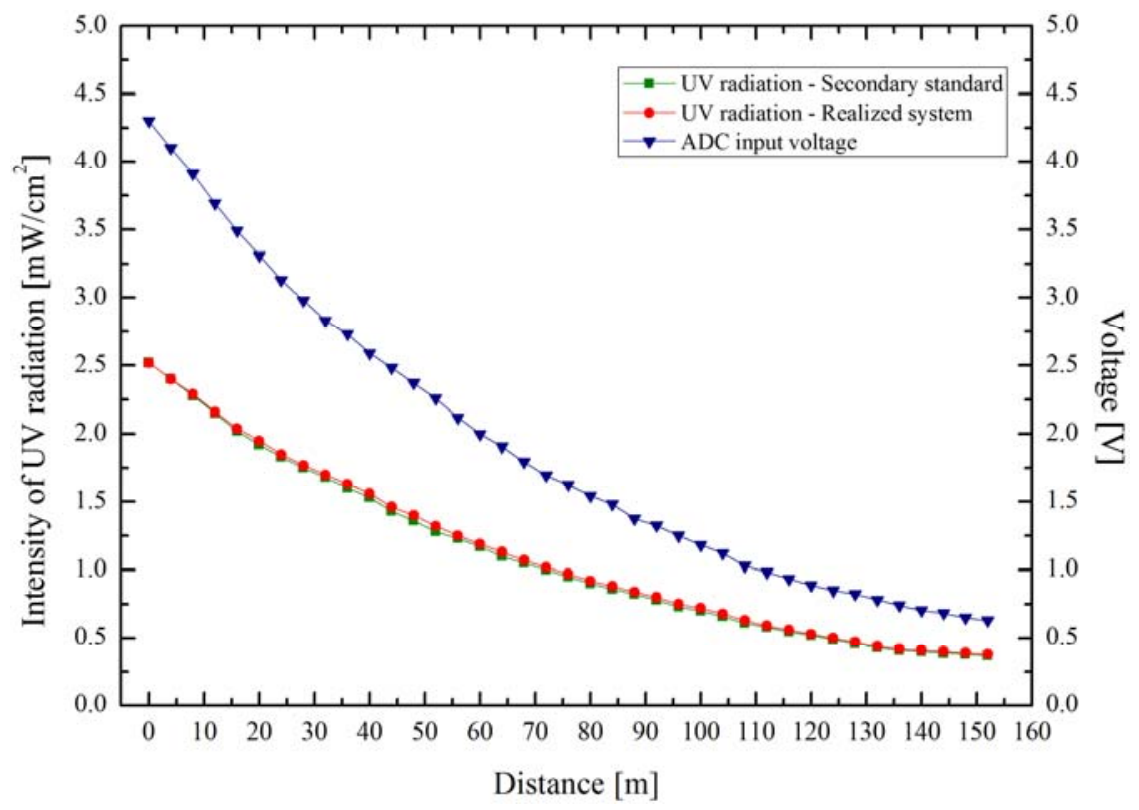

Figure 13. Measurement characteristic with the normalized characteristic of the realized system

\section{CONCLUSION}

The measurement of UV radiation is important for the design of efficient and reliable PV tracking systems. In this paper we presented the realization of a wireless system for UV radiation measure- ment. The special custom-made line platform was constructed in order to simplify calibration procedure and make it more reliable. The structure of the realized system was described in detail as well as the calibration procedure. As it is a wireless system and can be connected to a PC along with a matching PC 
application it would represent a single system. The realized system was calibrated and the test results obtained before and after calibration were presented. The results obtained with the third-order polynomial correspond to the results obtained by the secondary measurement standard. This system was designed to be a part of the PV tracking system whose realization is currently underway. The system has a universal use since it has a flexible hardware structure and with the minimal hardware and software changes it can become a part of any weather station. Future research will be related to the improvement of the system and its implementation in PV tracking systems.

\section{REFERENCES}

[1] C.R. Osterwald, J.P. Benner, J. Pruett, A. Anderberg, S. Rummel, L. Ottoson, Degradation in weathered crystalline-silicon PV modules apparently caused by UV radiation, Conference Proceedings „3rd World Conference on Photovoltaic Energy Conversion“, Osaka, 2003, 2911-2915.
[2] A comparison of Spectroradiometers to Radiometers for UV Radiation Measurements, Solar Light, Glenside.

[3] User Manual for the UV Radiation Sensors types UV3pA, $B$ and $A B$, Delta-T Devices, Cambridge 2003.

[4] G. Seckmeyer, A. Bais, G. Bernhard, M. Blumthaler, C.R. Booth, K. Lantz, R.L. McKenzie, Instruments to Measure Solar Ultraviolet Radiation, Part 2: Broadband Instruments Measuring Erythemally Weighted Solar Irradiance, World Meteorological Organization, Geneva 2001.

[5] Ultraviolet selective SiC based UV sensor SIC01L-5, Scitec Instruments, Cornwall.

[6] J. G. Graeme, Photodiode amplifiers: op amp solutions, McGraw-Hill, New York 1997.

[7] R. Mancini, Op Amps For Everyone, Texas Instruments, Dallas 2002.

[8] Y. Ohno, NIST Measurement Services: Photometric Calibration, National Institute of Standards and Technology, Gaithersburg 1997.

[9] T.C. Larason, C. L. Cromer, Sources of Error in UV Radiation Measurements, Journal of Research of the National Institute of Standards and Technology, 106 (2001) 649-656.

\section{РЕАЛИЗАЦИЈА И КАЛИБРАЦИЈА БЕЖИЧНОГ СИСТЕМА ЗА МЕРЕЊЕ ИНТЕНЗИТЕТА УВ ЗРАЧЕЊА}

Сажетак: У овом раду приказана је реализација једноставног бежичног мерног система за мерење интензитета УВ зрачења, који је базиран на фотодиоди као сензору. Систем је реализован како би био саставни део ротирајућег фотонапонског система, као и пратеће метеоролошке станице који су тренутно у фази развоја на Електронском факултету у Нишу. Приказан је развој хардвера, као и поступак калибрације реализованог система, закључно са експерименталним резултатима пре и после калибрације.

Кључне ријечи: УВ зрачење, фотодиода, бежични мерни систем, RF пренос података, калибрација. 